
DOI: http://dx.doi.org/10.4314/njbas.v25i2.7

\title{
Gongola Basin Crust-Mantle Structural Analysis For Hydrocarbon Investigation Using Isostatic Residual Gravity Anomalies
}

\author{
${ }^{* 1}$ E. E. Epuh and ${ }^{2}$ E. O. Joshua \\ 1Department of Surveying and Geoinformatics, University of Lagos, \\ 2Department of Physics, University of Ibadan \\ [ ${ }^{\star}$ Corresponding Author: Email: eeepuh@yahoo.com]
}

\begin{abstract}
The isostatic residual gravity anomaly data of Gongola basin was computed by removing from the Bouguer gravity anomaly field, a regional gravity field calculated for compensation of masses of surface topography. The regional gravity field was computed using the Airy-Heiskanen isostacy model with compensation at the crust-mantle discontinuity. The free air, residual isostatic anomaly, density distribution maps and 2.5D gravity models were utilized in the definition of the basin's crust-mantle structures. Results showed that: (1) the free air anomaly depicted the edge effect anomaly which correlates with the slope and rise at the NE zone. (2) The isostatic residual anomaly showed three zones: the overcompensated (NE-SE), undercompensated (NW-SW) while the hydrostatic equilibrium zone was found to be the transition between the undercompensated and the overcompensated zones. The distribution of rock densities within the exposed crust is not unimodal. The main component is the granodioritic ones $2.65-2.72 \mathrm{~g} / \mathrm{cm}^{3}$ consisting of plutonic rocks. The granitic component $2.60-2.64 \mathrm{~g} / \mathrm{cm}^{3}$ is common within the subsurface. The high velocities $(6.2 \mathrm{~km} / \mathrm{s})$ and the modeled high densities from $2.78-2.83 \mathrm{~g} / \mathrm{cm}^{3}$ suggest that the materials comprises high-grade metamorphic mafic intrusive and volcanic rocks. (3) The change in the crustal thickness along the profiles due to intra sediment and basement intrusive provide a measure of the amount of heating that occurred during rifting. Thus, the gravity across the rift system is found to be due to upwelling of low density hot materials which has also affected the hydrocarbon in place. (4) The crustal thickness together with the depositional architecture (e.g. porosity and permeability) should be used to determine the subsurface fluid circulation in terms of hydrocarbon exploration within the rifted basin. The intrusives are potential targets for solid minerals.
\end{abstract}

Key word: Bouguer, Airy Heiskanen model, isostatic residual, free air, isostatic regional gravity, 2.5D gravity model.

\section{INTRODUCTION}

Gongola basin gravity surveys were carried out to solve problems of hydrocarbon prospecting within the basin (Figure 1). These surveys were mostly focused to know the following: a) the tectonic, lithologic and petrographic demarcation of the area for hydrocarbon mapping, b) the delimiting of promising zones and areas for more detailed geological and geophysical exploration, c) the discovery of local structures favouring the accumulation of mineral deposits. In addition, the gravity surveys also focus on regional scale geological mapping, in understanding the crustal thicknesses which are important tectonic elements either in hydrocarbon or mineral exploration.
The principle of isostacy states that mass excess represented by topographic loads at the surface are compensated by mass deficiencies at depth which are referred to as isostatic roots. The effects of these mass deficiencies are not accounted for in the Bouguer reduction and there exist an inverse correlation between broad Bouguer anomaly lows and positive topography. The Isostatic correction removes the gravity anomaly effect of the Isostatic roots. Previous studies involving the gravity data acquired for this basin have recommended the re-computation of the basement depth and density distribution of the anomalous mass. In Gongola basin gravity surveys, graphical and polynomial fitting have been routinely used for 
the removal of regional gravity anomalies (Fairhead and Okereke, 1987; Nkwonta and Kene, 2005; Shemang et al., 2007; Okiwelu et al., 2010; Ugbor and Okeke, 2010). These methods introduce distortions due to overcorrection and as such, eliminate some part of the residual gravity anomalies that are required for the determination of the location, depth, form and density distribution of the anomalous mass in the basin. Also, there exist wide regional disturbances over Bouguer gravity associated with uplifted or depressed regions of the earth's crust as obtained in Gongola basin. These variations in crustal thickness (roots or anti-roots) which are isostatic in nature, give rise to broad anomalies in Bouguer gravity at the surface of the basin. Their removal is significant in the determination of an optimum residual anomaly. These disturbances cannot be wholly accounted for by the use of high order polynomial models since they are isostatic in nature. Based on this, the use of isostatic correction is preferred to polynomial model approach in this regional anomaly determination. Also, isostatic reduction attempts to remove the attraction of compensating masses achieving a strong smoothing of the anomalous gravity field such that the gravity maps reveal more clearly. The Isostatic anomaly is based on an accepted geologic concept rather than mathematical filter.

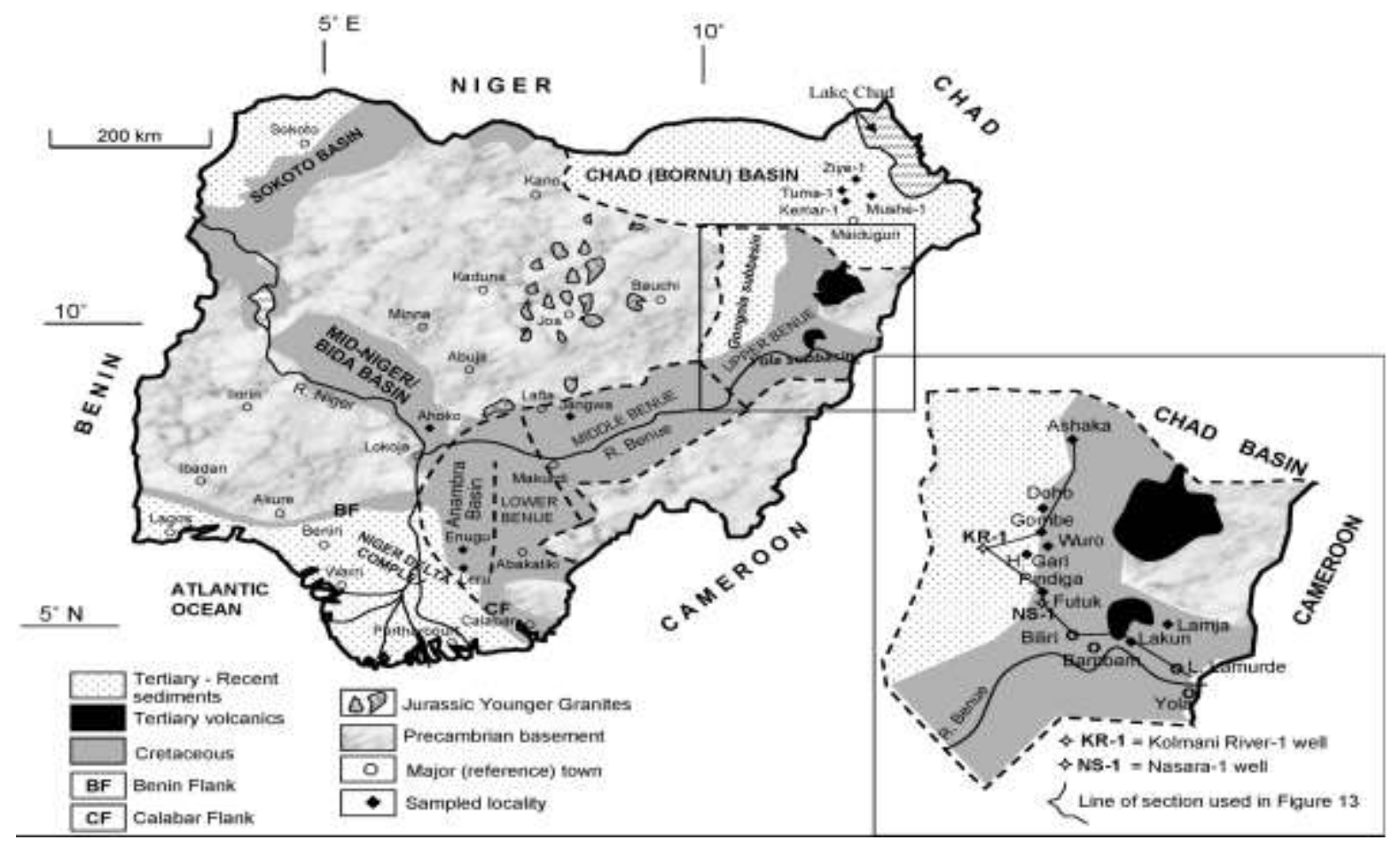

Figure: 1: Sketch geological map of Nigeria showing the inland basins and sample localities. (inset: upper Benue trough magnified (Source: Obaje et al., 2006)

This paper explores the application of the free air and isostatic residual anomalies computed using the Airy-Heiskanen correction in the determination of the source geometries and density distributions within the crust that are of interest in the analyses of the crustal structures and tectonic of the basin. Additional geophysical data such as seismic reflection and well log observation were incorporated into the determination of the velocity, density and the basement architecture.

\section{Geology of the Basin}

The Benue Trough is located at a major reentrant in the West African continental margin. It is bordered to the south-west by the Cenezoic Niger Delta and extends transversely northwards to the Chad basin. The margins of the Benue Trough are collinear both the Charcot and chain fracture zones of the 
equatorial Atlantic. The evolution of the Benue Trough is closely linked with the opening of the South Atlantic. Details on the sequence of events that led to its formation alongside other sedimentary basins in Nigeria are contained in the various literatures (King, 1950; Cratchley and Jones, 1965; Wright, 1976; Benkhelil, 1982; Whiteman, 1982). It is a rift basin with plate dilation leading to the opening of the Gulf of Guinea (Benkhelil, 1989; Fairhead and Binks, 1991). Benkhelil (1989) also suggested that the evolution trough could also be as a result of tension resulting in a rift or wrench related fault basin. Mesozoic to Cenezoic magmatism has accompanied the evolution of the tectonic rift as it is scattered all over and throughout in the trough (Coulon et al., 1996; Abubakar et al., 2010). A magmatic old rift was also suggested for the Gongola basin by Shemang et al. (2001) while Abubakar et al. (2010) suggested the evolution as a combination of mantle upwelling or rise of a mantle plume which resulted in crustal stretching and thinning and the emplacement of basic igneous material within the basement and sediment which resulted in rifting. The Benue Trough trends NE-SW and the northernmost end (upper Benue Trough) bifurcate into two arms - the Gongola and the Yola arms (sub basins). The Gongola basin of the upper Benue Trough is a North-South trending arm of the $1000 \mathrm{~km}$ long Benue Trough. These sub basins contain thick sediment accumulations (mainly Cretaceous) in excess of $5 \mathrm{~km}$ deposited under varying environments. The sediments have been subjected to main tectonic phases which account for the observed folding, faulting and fracturing of the rocks. Reviews of the geology and stratigraphic successions in the Benue Trough with details on each formation, bed thickness, lateral extensions and stratigraphic locations are found in Carter et al. (1963); Ofodile (1976); Petters (1982); Petters and Ekweozor (1982); Obaje (1994); Obaje et al. (2006). Details on the evolution and stratigraphic framework of the Chad basin are given in Avbovbo et al (1986) and Olugbemiro et al. (1997). Details on the stratigraphic succession in the Benue Trough, the Chad basin and the Mid-Niger Basin are shown in Figure 2.

\section{METHODOLOGY \\ The Airy-Heiskanen Isostatic Model}

The model is applied under the following assumptions (Rummel et al., 1998; Kuhn, 2003 and Ilk and Witte, 2007) that the isostatic compensation takes place completely and locally, i.e. the compensation mass is directly under the regarded topographic mass which makes the compensation depth variable (Figure. 3).

The root thickness $t_{s p}$ for spherical approximation is obtained as (Rummel et al., 1998 and Ilk and witte, 2007).

$t_{s p}=(R-T)\left[1-\sqrt[3]{1-\frac{\left((R+H)^{3}-R^{3}\right) \rho_{c r}}{(R-T)^{3} \Delta \rho}}\right] \ldots$

$\mathrm{R}=$ radius of the earth $=6371 \mathrm{~km} . \quad T=$ normal thickness.

\section{Data Processing}

The Bouguer gravity anomaly was computed using the crustal density of $2.67 \mathrm{~g} / \mathrm{cm}^{3}$. The Bouguer gravity anomaly is shown in Figure 4 . The free air anomaly was computed to determine the gravity effects at the geoid level and the edge effect anomaly zone (continental margin -Fig 4). The weathered tertiary density value for the computation of the isostatic compensation using the Rummel et al., model (Eqn. 1) was obtained the available well log observation from the kolmani River within the project area. The velocity data obtained from the basin also showed that the density of the basement is $2.75 \mathrm{~g} / \mathrm{cm}^{3}$. The isostatic correction at each point is the sum of these gravitational effects. The isostatic residual anomalies were calculated by adding the isostatic regional anomalies to the Bouguer gravity anomalies. Nine different $2.5 \mathrm{D}$ models were used to evaluate the crustal and tectonic architecture of the basin. The seismic and well log data were used as constrain in the 2.5D gravity modeling in the determination of the 
density contrast of the sedimentary cover. This helped in the definition of the geometry and density distribution over the crust and upper mantle.

\section{RESULTS AND DISCUSSION}

\section{Results}

The results of the maps and the $2.5 \mathrm{D}$ gravity models are shown as follows: (1) Bouguer gravity anomaly (Figure 4); (2) free air anomaly map (Figure 5), and the isostatic residual anomaly map (Figure 6) respectively. The gravity models are shown in Figures 7-15 respectively.

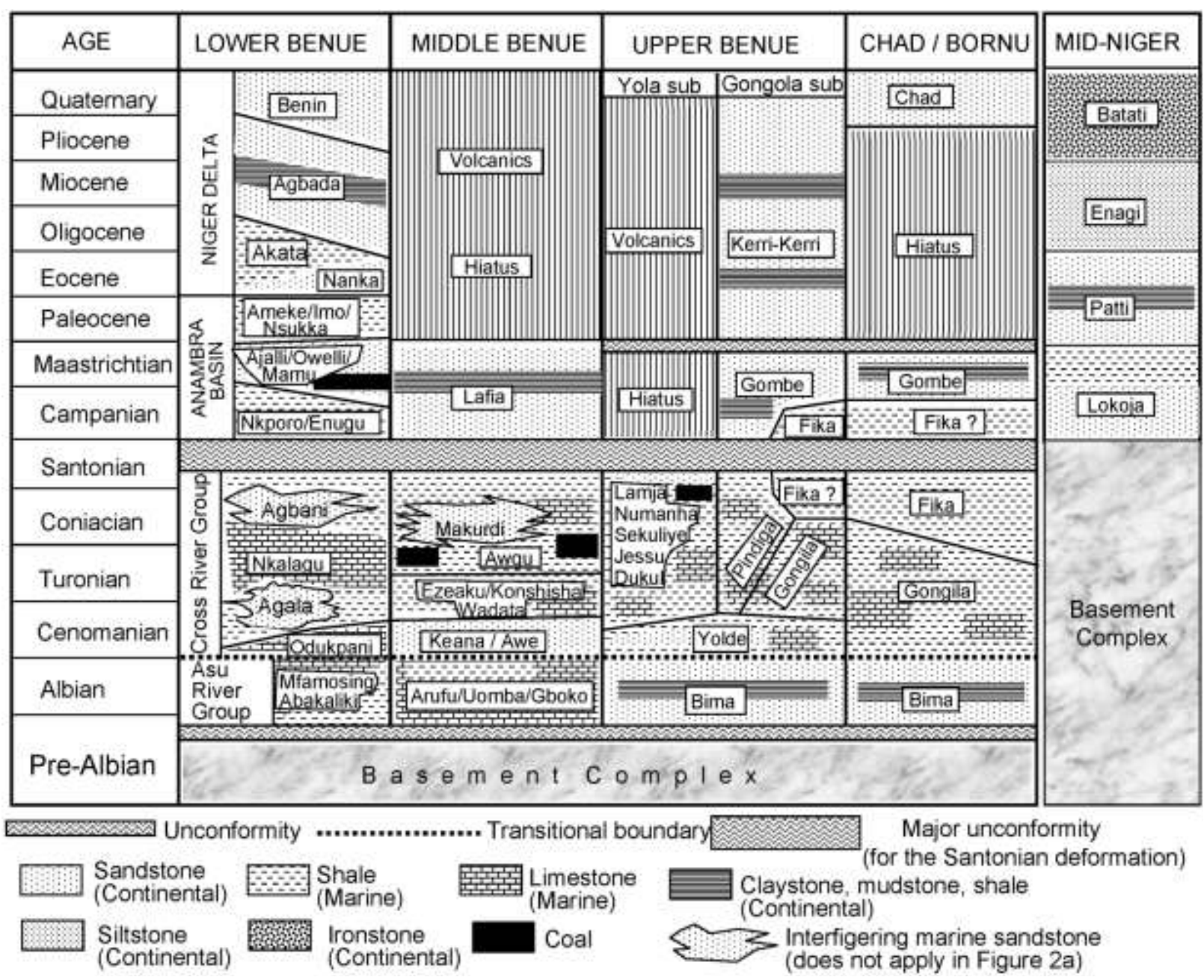

Figure 2: Stratigraphic Succession of Gongola Basin in the Benue Trough, the Nigerian Sector of the Chad Basin, the Mid-Niger basin and the Relationship to the Niger Delta. (Source: Obaje et al., 2006) 


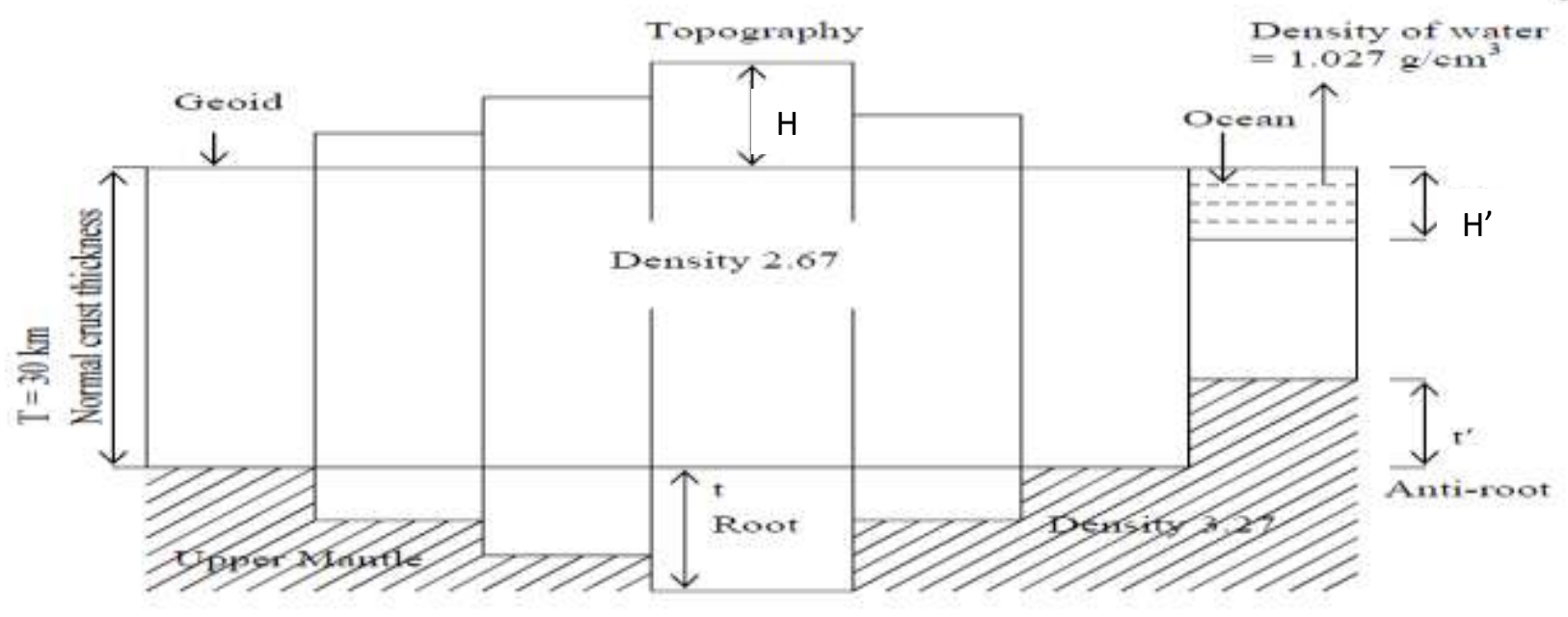

Figure 3: Airy-Heiskanen isostatic model in planar approximation (Source: Ilk and Witte, 2007)

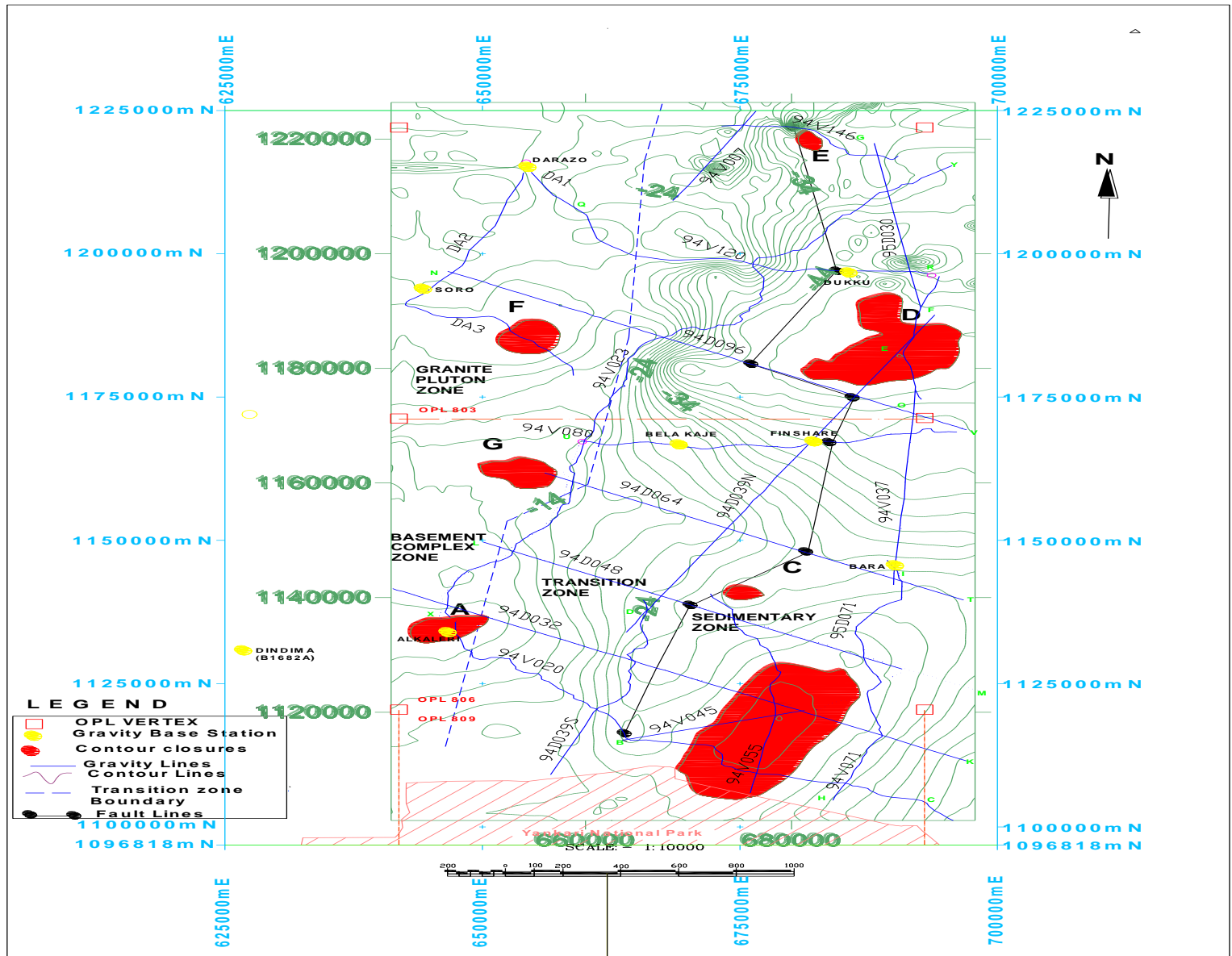

Figure 4: Bouguer Gravity Anomaly Map (Density 2.67) 
Epuh and Joshua: Gongola Basin Crust-Mantle Structural Analysis For Hydrocarbon.

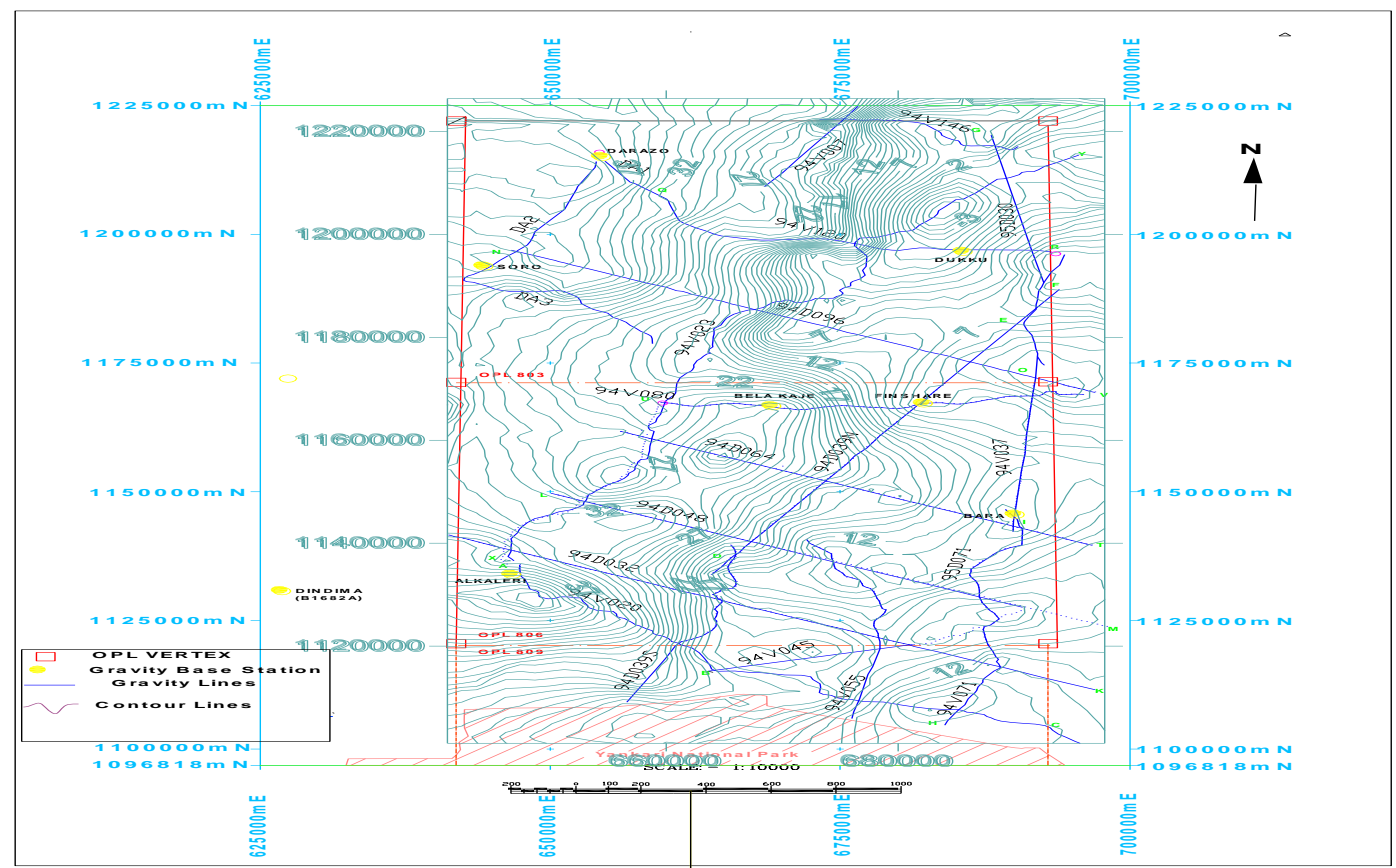

Figure 5: Free Air Anomaly Map (Contour interval = 1mGal)

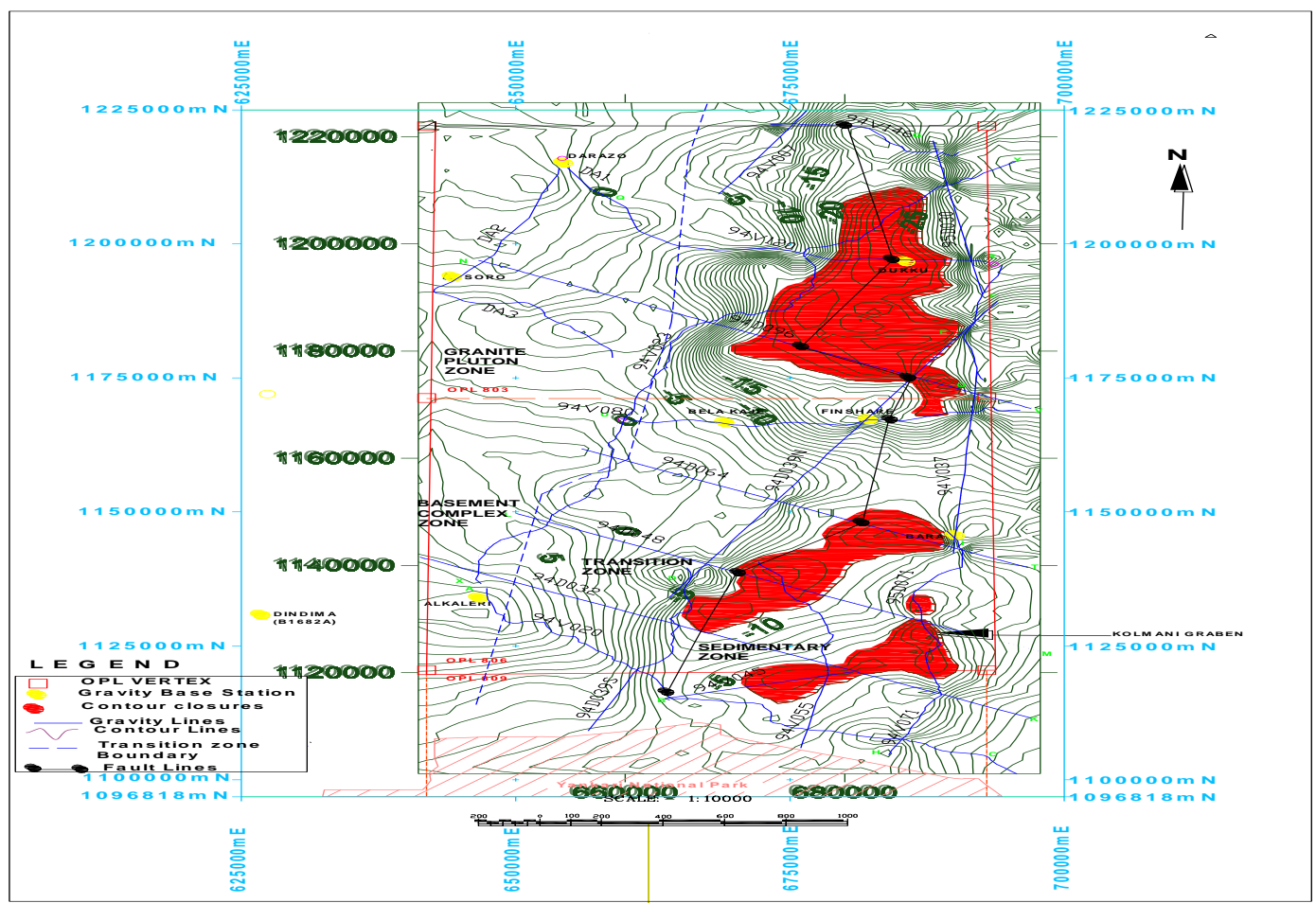

Figure 6: Isostatic Residual Gravity Anomaly Map Using Airy-Heiskanen Model C.I=1mGal

Analysis of the Gravity Anomaly Map and Models

Bouguer Gravity Anomaly Map

From the $2.67 \mathrm{~g} / \mathrm{cm}^{3}$ density Bouguer gravity anomaly map (Figure 4), the project area could be divided into four zones based on the following criteria: (a) the area with large negative anomaly (sedimentary zone -SE); (b) the area with positive anomaly (basement complex zone- SW); and (c) the area with linear 
contours (transition zone). The fourth zone lies in the NW and is called the granite pluton zone. The faults and fractures manifest themselves on the Bouguer gravity anomaly map as: (1) a consistent system or step-like anomaly pattern forming boundaries between areas of different Bouguer anomaly level, relief or texture; (2) disruptions and/ or deflections of Bouguer gravity anomaly trends indicated for example by abrupt changes in the amplitude of horizontal gradient; (3) linear or lace like Bouguer anomaly lows caused by fractured and/or weathered fault zones, by abnormally thick soils, by granites intruded into pressure minima or granitization all controlled by deep fault, fracture or shear zones; (4) narrow, linear Bouguer gravity anomaly lows or highs due to low density (e.g. pegmatites) and high density (e.g. diabase) rocks intruded into fault and fractured zones. The Bouguer gravity anomaly pattern also delineates blocks or shear lenses which have experienced differential horizontal and vertical movements. For example, the thick and dash lines on the map (Figure 4) that runs from the SE to the NE shows the fault zone separating the granite pluton/basement complex zone and the sedimentary zones within the project area.

\section{Free Air Anomaly Maps}

One of the most distinctive geophysical features of the rifted continental margins is the free air gravity edge-effect anomaly (Watts and Fairhead, 1999). In the Gongola basin, the free air anomaly shows positive values with a background value of $+26 \mathrm{mGal}$ in the NW and SW zones and $12 \mathrm{mGal}$ in the SE zone. The anomaly abruptly decreases to negative values towards the NE with a background value of $+3 \mathrm{mGal}$. The free air anomaly comprises of gravity high and a low which correlates with slope and rise of the Northeast zone of the project area (Figure 5). This zone has a sediment thickness of $7.0 \mathrm{~km}$. It then follows that the sediment loading has contributed significantly to the edge effect anomaly. The high is as a result of metamorphosed volcanosedimentary surrounding which are dense while the low is the result of the downward displacement of the relatively low density crust into a denser mantle by the sediment load. Together, these anomalies define the sedimentation anomaly of the zone. Okereke et al. (1988) opined that the rift feature originated in the Cretaceous at the time that Africa and South America began to separate.

\section{DISCUSSION}

The isostatic residual anomaly shows three zones within the basin. The overcompensated zone has large negative anomaly values. These negative anomalies are as a result of the presence of sediments. The velocity data showed that the area is dominant of dolomite and shale. The second zone shows zero anomaly values indicating a zone of hydrostatic equilibrium. The third zone has positive anomaly values indicating the zone of undercompensation. The paired linear high-low anomalies commonly form the gravity signature of plate tectonic sutures (Gibb and Walcott, 1971; Gibb and Thomas, 1976; Gibb et al., 1983). The basin's isostatic residual gravity anomaly values range between a gravity minima of $-30 \mathrm{mGal}$ and a gravity high of $+14 \mathrm{mGal}$. Finding the cause of these paired highs and lows is not always simple, although the following factors are frequently mentioned. The Lows marking sutures may be caused by (1) sialic crust downwarped by the weight of thrust plates (Karner and Watts, 1983); (2) accumulation of sedimentary deposits in the downwarped areas, and (3) belts of granitic intrusions (Gibb, 1968). The highs are formed by mafic rocks emplaced during the early rifting event that formed a continental margin now altered by collision (Cook and Oliver, 1981; Lillie, 1985) and dense rock upthrusted by collision (potentially either dense lower crustal rocks, dense massif rocks formed during an early rifting or dense accreted rocks). The isostatic residual gravity anomaly map showed the presence of graben and horst structures at the southeast and northeast zone of the project area. The graben and horst structures were initiated during the rifting of the basin and this produced a principal fault which runs in the SENE direction. The faulted blocks and their associated transgression and regression appear to have controlled the lithostratigraphic 
development along the edge of the basin. The graben (Kolmani Trough) correlates with gravity low southeast of the basin and the gravity modeling constrained by seismic reflection data indicate that this feature is associated with thick section of the cretaceous sediment $(5000 \mathrm{~m})$. West of the graben is a horst with a maximum sediment thickness of $2000 \mathrm{~m}$. The horst correlates with the gravity high beyond the linear section. The horst is a marginal ridge and in all cases marginal ridges produce relatively high amplitude gravity anomalies (Bird, 2001). The horst also is a thermal uplift which produced the ridge that trapped sediments leading to thick accumulation of sediments in the Kolmani graben. This analysis is consistent with the evolution of the basin which involves continental rifting (Okereke et al., 1988). The linearity in both the Bouguer gravity anomaly and the residual gravity anomaly maps (647393 - 665150E and 1120496-1221752N) is indicative of strike features along the southeast-northeast direction. It reveals a structural alignment showing that the region is tectonically active. It also shows the presence of block faulting. This block faulting appears to be due to local isostatic adjustment related to deep basement structure. The fault line (Figures 4 and 5) shows the tectonic activity within the sedimentary (overcompensated) zone. It is also observed from seismic investigation that the sedimentation in the overcompensated zone began with the deposition of continental, shallow marine, open marine and fluvio-deltaic clastics sediments of the campanian/Maastrician age. These sediments belong to the Pindiga and Yolde stratigraphic formations. The subcrustal density variation map (Figure 6) shows that the southeastern uncompensated sedimentary zone has the most favourable low density for hydrocarbon accumulation.

\section{Discussion on Models}

Nine profiles namely: 94V020, 94V120, 94V146, 94D032, 94D039, 94D048, 94D064, 94D096 and a composite profile 94V071/95D071/94V037 that passed through the closures $(A, B, C$ and $D)$ in the isostatic gravity anomaly map were used to carry out the gravity modeling of the basin.

The modeled cross sections for lines 94V020 (Figure 7) and 94D032 (Figure 8) and show granitic intrusions with positive density contrast of $+0.08 \mathrm{~g} / \mathrm{cm}^{3}$ and $+0.06 \mathrm{~g} / \mathrm{cm}^{3}$ respectively. This shows the presence of intrasediment sill and intrabasement volcanic intrusions. The basement outcrops within the first $20 \mathrm{~km}$ in model $94 \mathrm{~V} 020$ and between $0 \mathrm{~km}$ and $22 \mathrm{~km}$ in model 94D032. The large variations in amplitude and the steep gradient observed in these models are compatible with the structures formed by extensional tectonics of the basin (Okereke et al, 1988). The characteristics exhibited are evidence of block faulting and dyke intrusions occurring probably during the initial rifting of the basin. The sediment thickness varies from $2.0 \mathrm{~km}$ in the southwest to $6.0 \mathrm{~km}$ in the southeast part of the models.

The modeled cross sections for lines 94D039 (Figure 9), 94D048 (Figure 10), 94D064 (Figure 11), shows a thick sedimentary sequence which increases from $1.0 \mathrm{~km}$ in the southwest to a maximum depth of $5.0 \mathrm{~km}$ at the flanks of the basin. The sediments is underlain by a crystalline basement. The models also show the Kolmani graben as it extends towards the flanks. Figure 9 shows a basement ridge and a horst. The ridge is the extension of that observed in models 94V020 and 94D032. The gravity low and high at the graben are as a result of intrabasement intrusions.

The modeled cross sections 94D096 (Figure 12), 94V120 (Figure 13) and 94V146 (Figure 14) revealed the change in crustal structure and tectonic style (edge effect) of the northeastern part of the basin. They models show a thin sedimentary cover with a maximum thickness of $2.5 \mathrm{~km}$ in the northwest and a thick sedimentary cover in the northeast with a maximum thickness of $7.0 \mathrm{~km}$. This is the deepest part of the basin. The gravity low and high are due to intrabasement intrusions with various density contrasts. 
Nigerian Journal of Basic and Applied Science (December, 2017), 25(2): 51-65

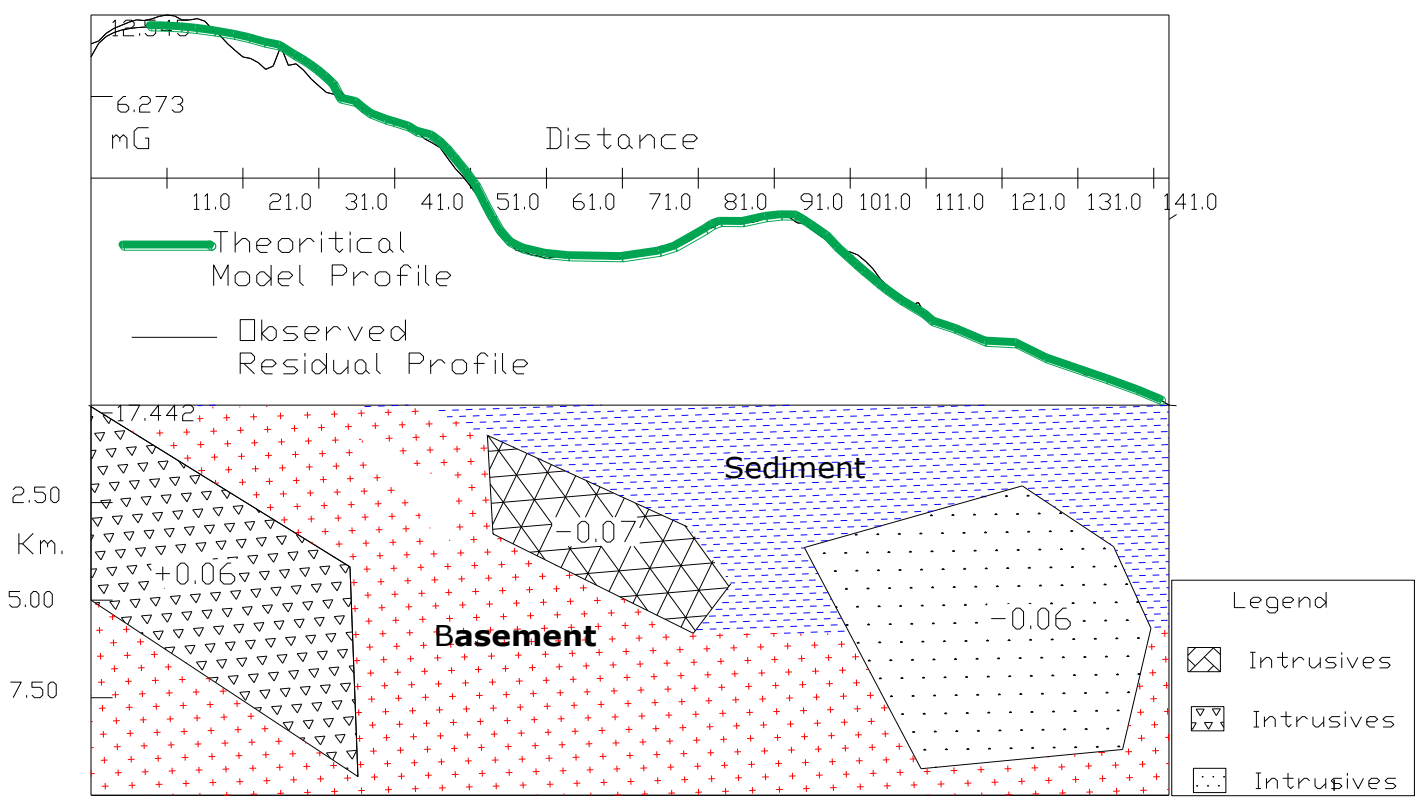

Figure 7: 2.5D model showing volcanic rocks intruding to the sedimentary sequence for Line $94 \mathrm{~V} 020$

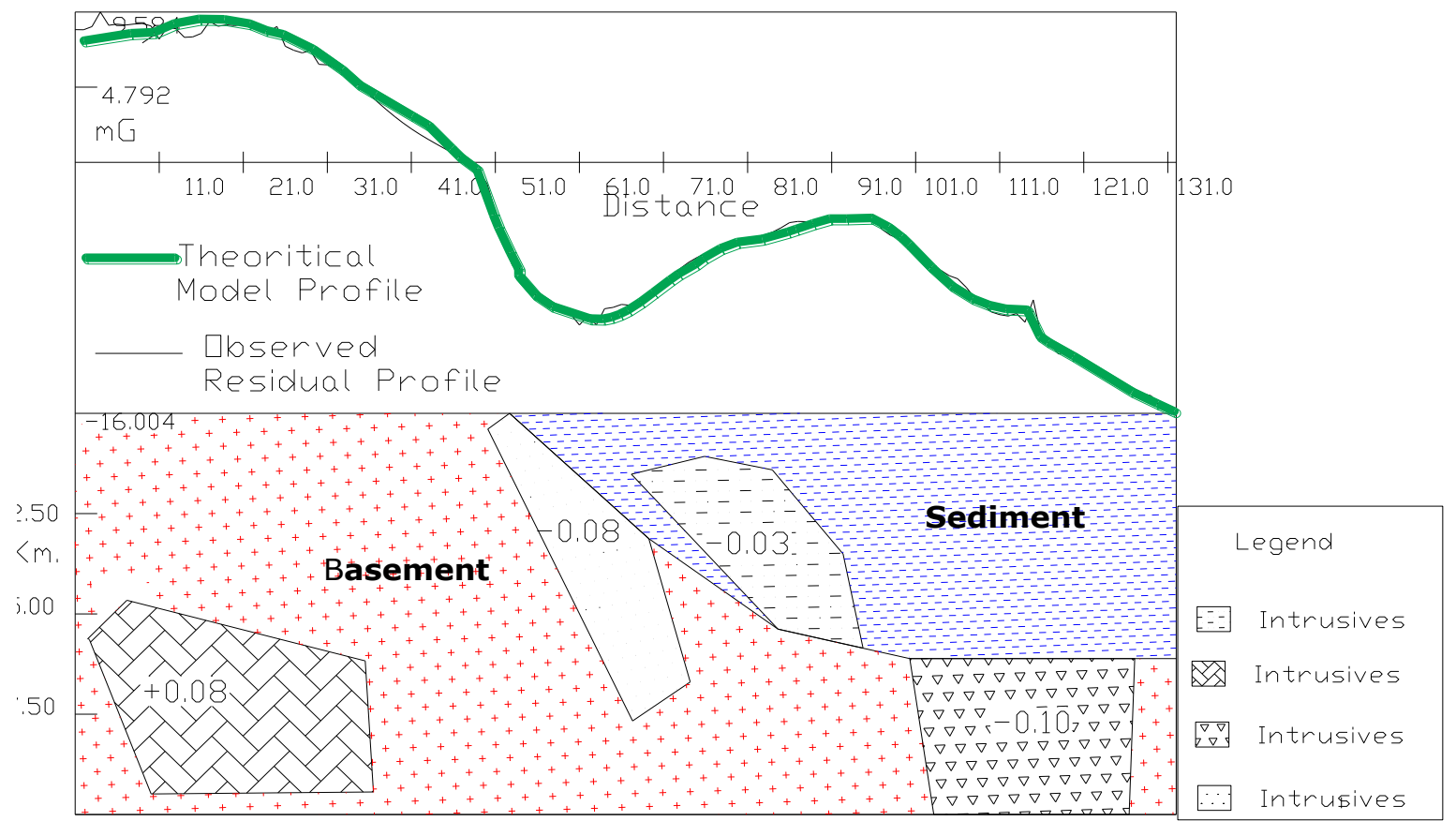

Figure 8: 2.5D model showing reverse faults that deformed the lower part of the sedimentary sequence and volcanic intrusive for Line 94D032. 
Epuh and Joshua: Gongola Basin Crust-Mantle Structural Analysis For Hydrocarbon.

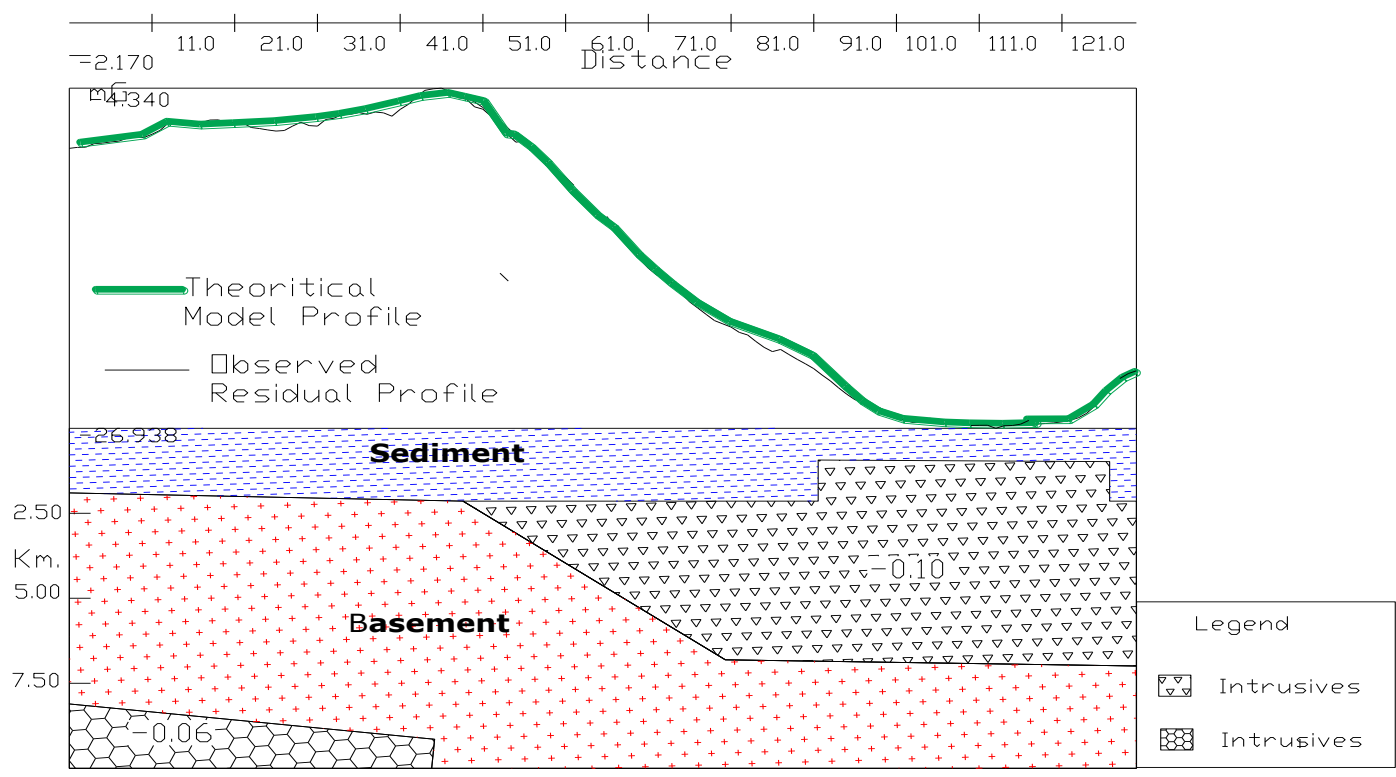

Figure 9: model showing block faulting and Intrusives for Line 94D039

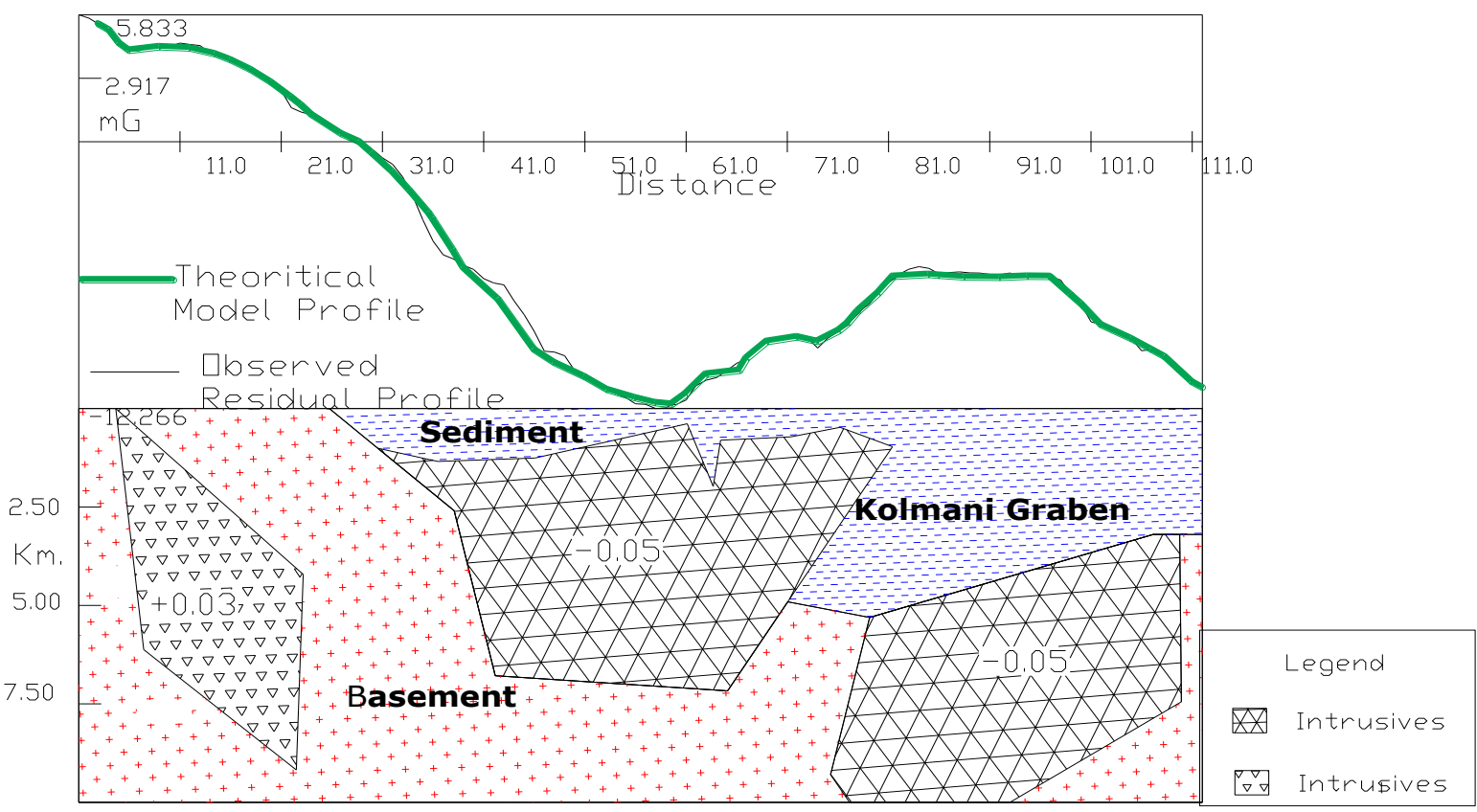

Figure 10: 2.5D model showing thick sedimentary cover and Intrusives for Line 94D048 


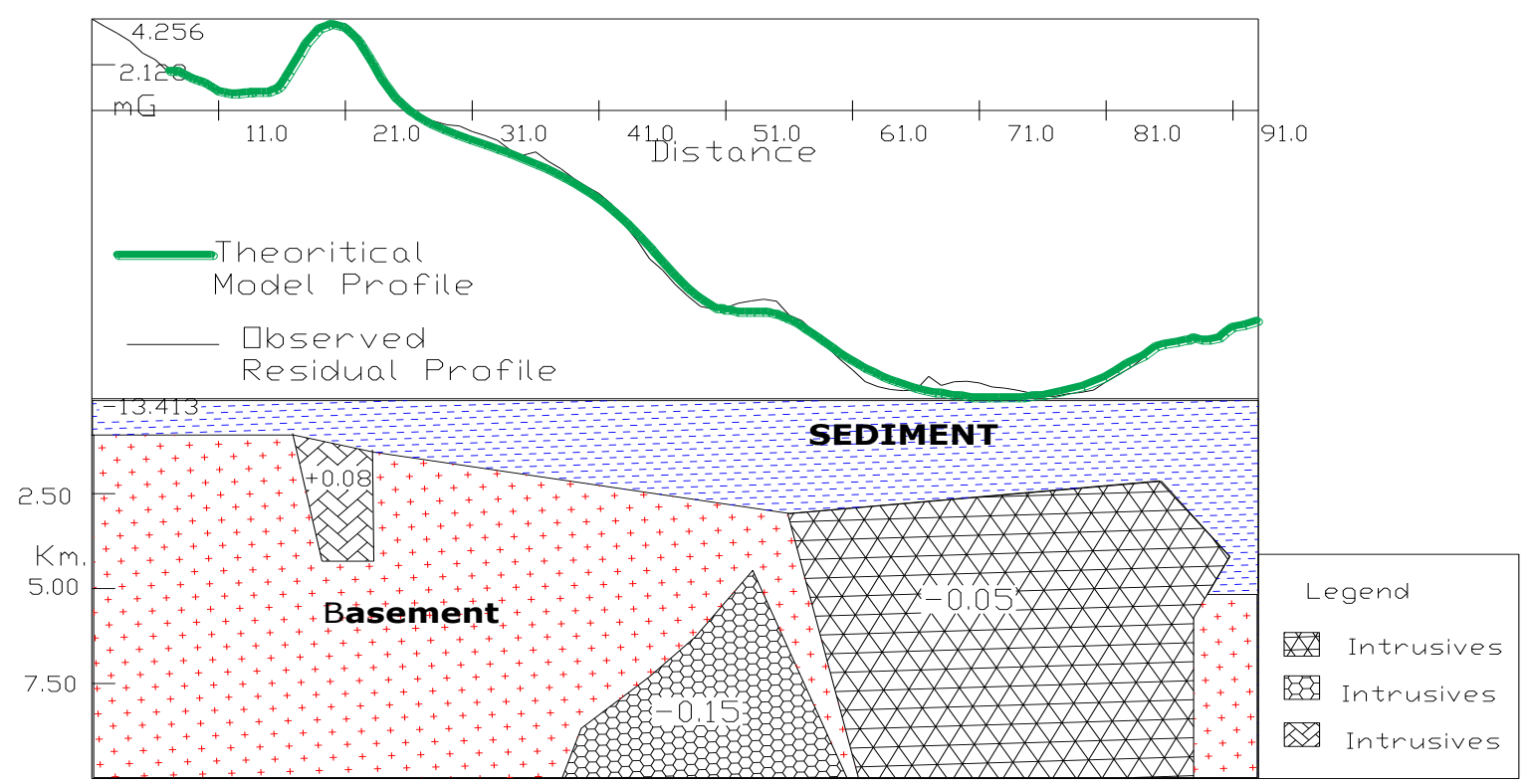

Figure 11: 2.5D model showing Block faulting, sediment and intrabasement intrusive for Line 94D064

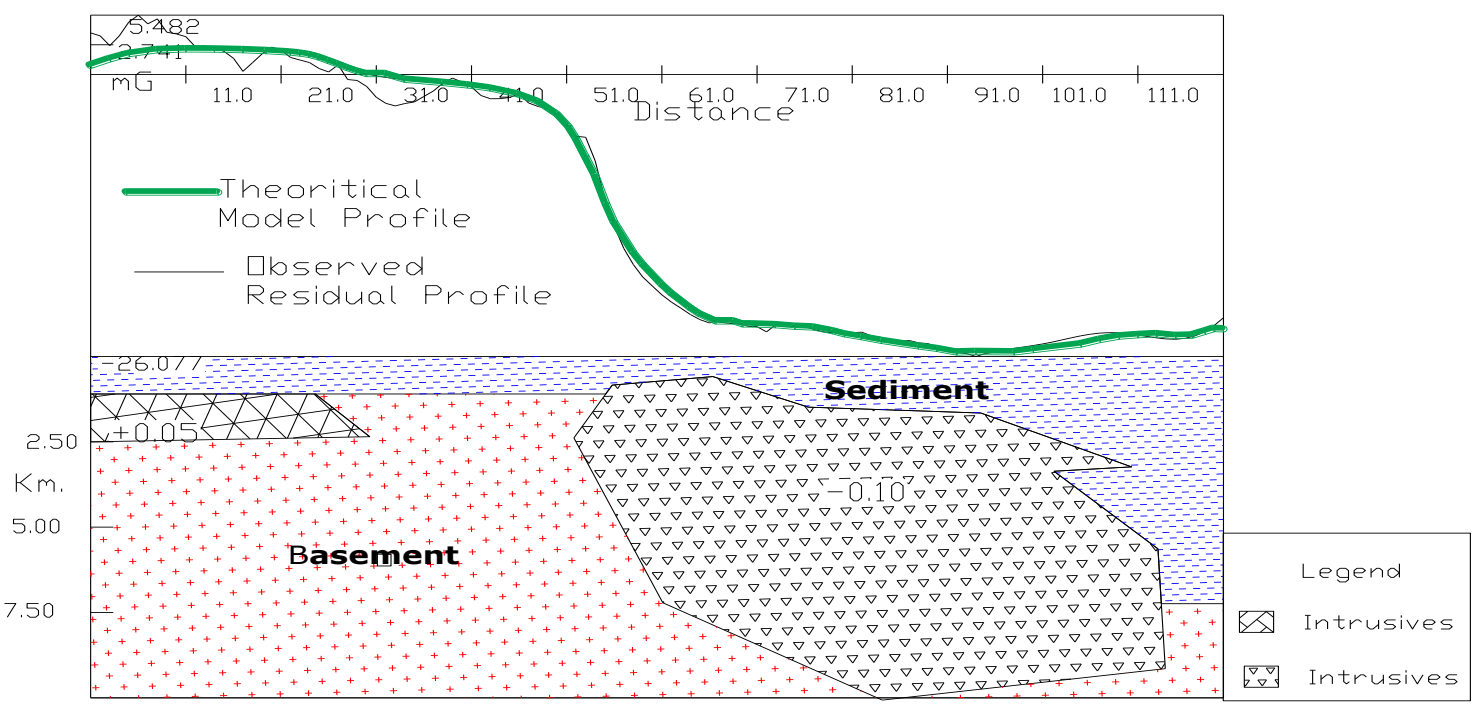

Figure 12: 2.5D model showing Block faulting, sediment and intrabasement dyke intrusive for Line 94D096

The modeled cross section for the composite profile 94V071/94D071/94V037 (Figure 15) shows the crustal structure and tectonics along the flanks of the basin. The intrabasement intrusion with density contrast of $-0.18,-0.14 \mathrm{~g} / \mathrm{cm}^{3}$ and the basement density contrast are the cause of the gravity low. The modeled cross section of the entire profiles within the basin revealed clearly the structure and change in tectonic style from the southeast to the northeast part of the basin flanks. The gravity models are not at variance with the proposed graben and horst structures of the flanks as inferred from the isostatic residual gravity anomaly map. The major intrusive with density $\left(2.65-2.72 \mathrm{~kg} / \mathrm{m}^{3}\right)$ suggest the presence of granodioritic rocks. The granitic components $\left(2.60-2.64 \mathrm{~kg} / \mathrm{m}^{3}\right)$ are also common within the crust. The high velocities $(6.2 \mathrm{~km} / \mathrm{s})$ and the modeled high densities 
Epuh and Joshua: Gongola Basin Crust-Mantle Structural Analysis For Hydrocarbon.

from $2.78-2.83 \mathrm{~g} / \mathrm{cm}^{3}$ suggest that the metamorphic mafic intrusive and volcanic materials comprises of high-grade rocks.

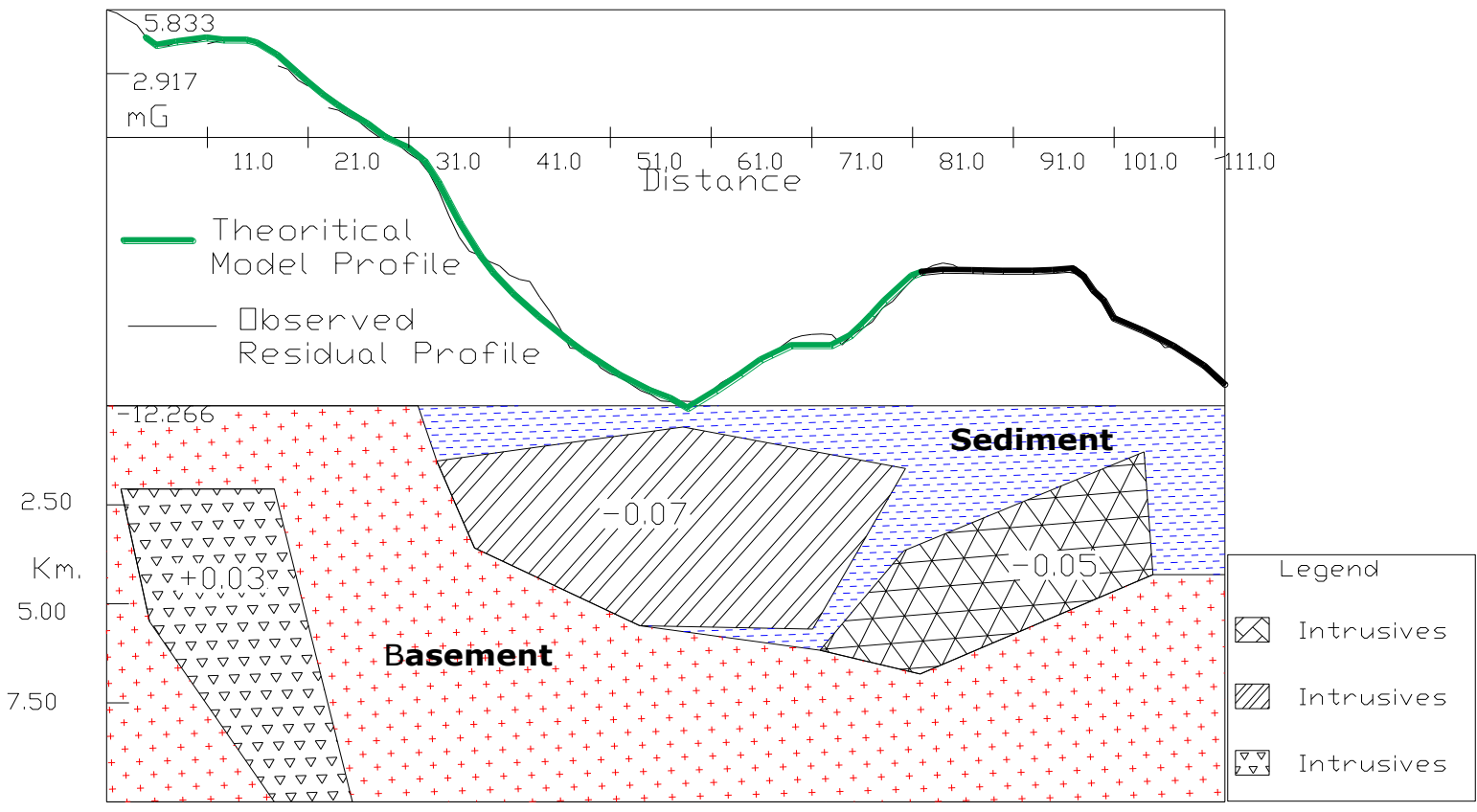

Figure 13: 2.5D model showing sediment and intrabasement intrusive for Line 94V120

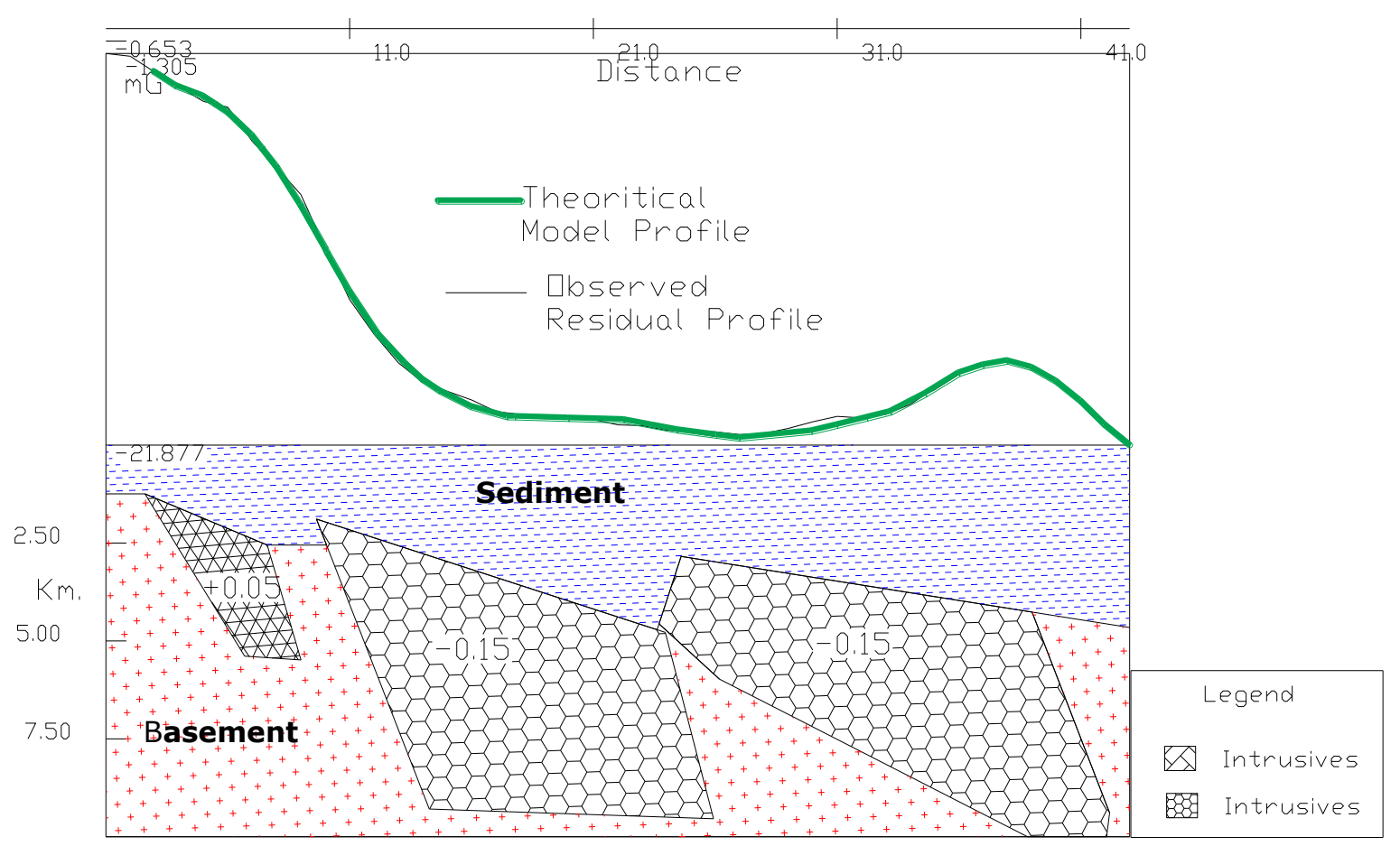

Figure 14: 2.5D model showing Block faulting, sediment and intrabasement intrusive for Line 94V146 


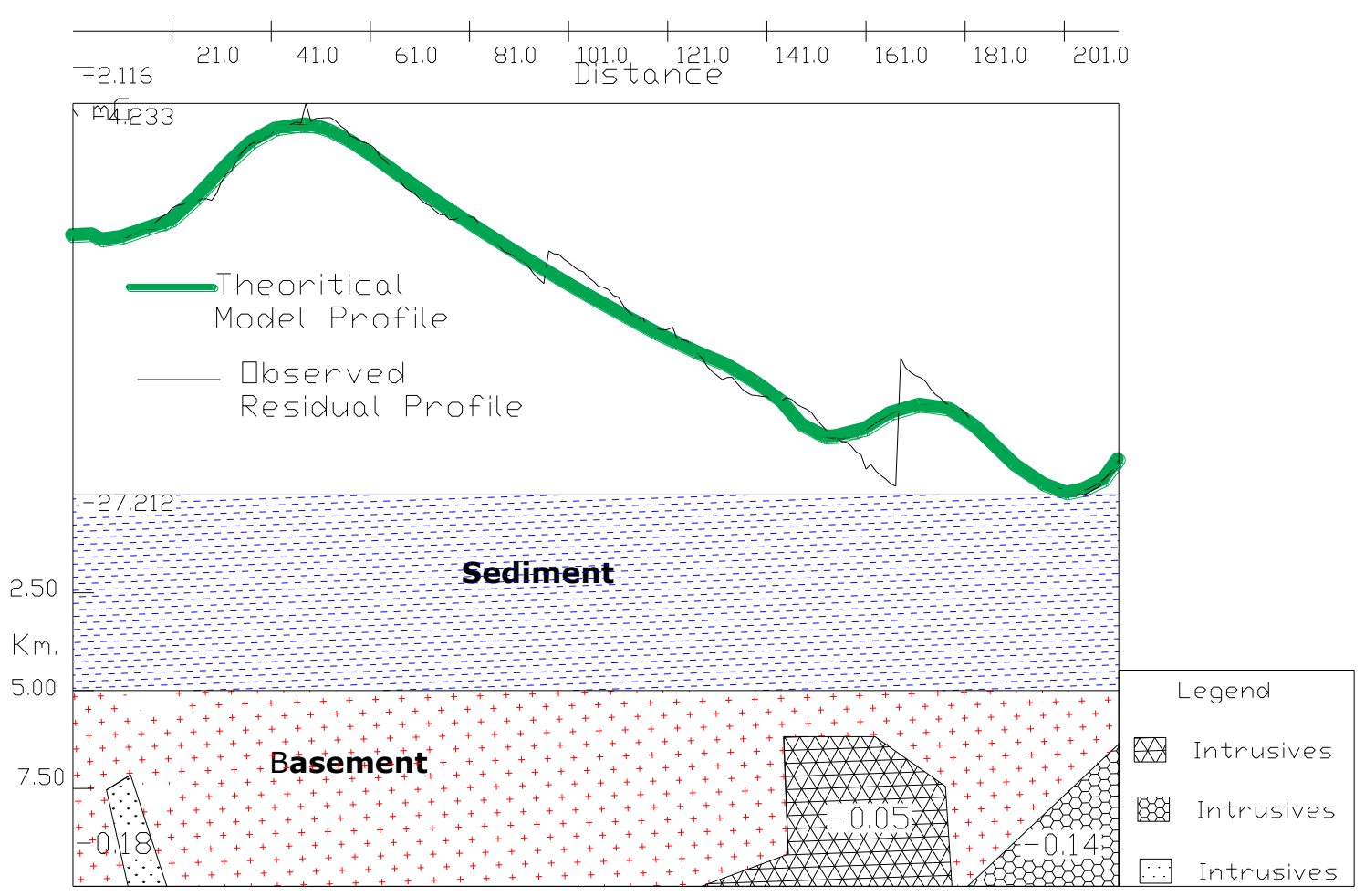

Figure 15: 2.5D model showing intra basement intrusives for 94V071/95D071/94V037

The integration of the gravity modeling results and that obtained from the free air and isostatic residual gravity anomaly map show that the closure A which lies on model profile 94V020 and 94D032 (Figure 6) with an amplitude of $5 \mathrm{mGal}$ is a synclinal structure. The closure $B$ which lies on model profile 94D048 has low amplitude of $-12 \mathrm{mGal}$. It is a basement ridge/ anticlinal structure with a favourable sediment thickness for hydrocarbon accumulation. The closure $B$ have similar structural features with closure $A$ as shown in modeled profile 94D064 and 94V037 part of the composite profile. The closure $\mathrm{C}$ which lies at the northeast part of the basin with a low amplitude of $-25 \mathrm{mGal}$ and a deep sediment thickness between $5.0 \mathrm{~km}$ and $7.0 \mathrm{~km}$ caused by block faulting. The sediment sequence has granitic intrusions as shown in the modeled profiles 94D096 and 94V120. The closure $D$ which lies on the modeled profile 94V146 has low amplitude of $-15 \mathrm{mGal}$ and a basement depth of up to $5 \mathrm{~km}$. Based on the integrated results of the isostatic residual anomaly, closures $A$ and $B$ which lies in the Kolmani Graben have the most favourable structural setting for hydrocarbon accumulation.

\section{Implication for Hydrocarbon Exploration}

Our modeling results have several implications in terms of hydrocarbon exploration. The determination of the crustal structures and density distribution beneath the sedimentary basin is necessary in respect of the source rock. The crustal structure has shown the presence of granitic intrusives which will cause a heating effect within the subsurface. Also the change in crustal thickness along the profiles provides a measure of the amount of extension and hence, heating that occurred at the margin during rifting (Watts and Fairhead, 1999). Since the rate of maturation of organic sediment depends strongly on the duration of heating, the crustal thickness can be used together with the depositional architecture (e.g. porosity and permeability), to better understand the subsurface fluid circulation in the rifted basin. This also will determine the productivity of oil and gas within the basin.

\section{CONCLUSION}

The free air and isostatic residual gravity anomaly data provided a considerable insight 
into the crustal structural and tectonic style of Gongola basin. Although modeling of potential field data always yield non-unique results, we have reduced the ambiguity to a significant degree by combining isostatic findings and gravimetric modeling with constraints from deep seismic reflection data. The results have shown the presence of block faulting and volcanic rocks. . The graben and horst sediment filled structures indicate that the structures are tectonically significant. The basement rocks that lie beneath the cretaceous Gongola sediments and overlying the sedimentary sequence are the overriding factor for the cause of the series of positive and negative gravity anomalies in the Gongola basin. The high density material is likely mafic in nature and is related to magmatic activity during the break up phase of the continental margin formation.

\section{ACKNOWLEDGEMENT}

We thank Shell Nigeria Exploration and

Production Company (SNEPCO) for the release of the data used in this research.

\section{REFERENCES}

Abubakar, Y. I; Umegu, M. N; Ojo, S. B. (2010): Evolution of Gongola Basin Upper Benue Trough Northeastern Nigeria. Asian Journal of Earth Sciences, J:6272:

Avbovbo, A. A; Ayoola, E. O and Osahon, G. A (1986): Depositional and Structural Styles in the Chad basin of Northeastern Nigeria. AAPG Bulleting, 70: 1787-1798.

Benkhelil, J. (1989): The Origin and Evolution of the cretaceous Benue Trough (Nigeria). Journal of African Earth Science, 8: 251-282.

Bird, D. E. (2001): Shear Margins: ContinentOcean Transform and Fracture Zone Boundaries. The Leading Edge. 20(2): 150-159.

Carter, J. D, Barber, W, Tait, A. E, Jones, J. P. (1963): The Geology of part of Adamawa, Bauchi and Borno Provinces in North Eastern Nigeria.
Cook, F. A and Oliver, J. E (1981): The Late Precambrian-early Palezoic continental edge in the Appalachan orogen. American Journal of Science, 281: 993-1008.

Coulon, C; Vida,P; Dupoy,C; Baudin,P; Pupof, M; Maluski, $\mathrm{H}$ and Hermite, D (1996): The Mesozoic to Early Cenezoic Magmatism of the Benue Trough (Nigeria): Geochemical Evidence for the Involvement of the St. Hlena Plume. Journal of Petroleum, 37:13411358.

Cratchley, C. R and Jones, G. P (1965): An Interpretation of the Geology and Gravity Anomalies of the Benue Valley of Nigeria. Overseas geological survey, London. Journal of Geophysics, 1:1-26.

Fairhead, J. D and Okereke, C. S (1987): A Regional Gravity Study of the West African rift System in Nigeria and Cameroun and its Tectonic Implication. Tectnophysics, 143:141-159.

Fairhead, J. D and Binks, R. M (1991): Differential Opening of the Central and South Atlantic Oceans and the Opening of the West Africa Rift System. Tectonophysics, 187:191-203.

Gibb, R. A (1968): A geological interpretation of the Bouguer anomalies adjacent to the Churchill-Superior boundary in th northern Manitoba. Can. J. Earth Sci., 5:439-453.

Gibb, R. A., and Thomas, M. D (1976): Gravity signature of fossil plate boundaries in the Canadian Shield. Nature, 262: 199200.

Gibb, R. A and Walcott , R. I (1971): A Precambrian suture in the Canadian Shield. Earth planet. Sci. Lett,10: 417422.

Gibb, R. A; Thomas, M. D; LaPointe, P. L; and Mukhopadhyay, M (1983): Geophysics of proposed Proterozoic sutures in Canada. Precambrian Res, 19, 349384.

Ilk, K. H and Witte, B (2007): The Use of Topographic-Isostatic Mass Informationin Geodetic Applications. Inaugural Lecture. Institute of Geodesy 
and Geoinformation, University of Bonn, Germany.

Karner, G. D and Watts, A. B (1983): Gravity anomalies and flexure of the lithosphere at mountain ranges. $J$ Geophys. Res, 88(10): 449-10,477.

King, L. C (1950): Outline and Disruption of Gondwanaland. Geol. Mag. 87: 353359.

Kuhn, M (2003): Geoid Determination with density hypotheses from isostatic models and geological information. Journal of Geodesy, 77: 50-65.

Lillie, R. J (1985): Tectonically buried continent/ocean boundary, Ouachita Mountain, Arkansas. Geology, 13: 1821.

Nkwonta, I. K and Kene, P. O (2005): Use of Aeromagnetics in Mineral/ structural Exploration in Nigeria. American Geophysical Union Spring Meeting 2005, abstract No. NS238-12.

Obaje, N. G (1994): Coal Petrography, microfossils and paleoenvironments of Cretaceous Coal measures in the middle Bebue Trough of Nigeria. Tuebinger Mikropalaeontologishe, 11: 1-165.

Obaje, N. G; Attah, D. O; Opeloye, S. A and Moumouni, A. (2006): Geochemical Evaluation of the Hydrocarbon Prospects of Sedimentary Basins in Northern Nigeria. Geochemical Journal, 40: 227-243.

Ofodile, M. E (1976): The Geology of the Middle Benue, Nigeria. Palaentological Institute, University of Uppsala, Special Publication, 4: 1-166.

Okereke, C. S (1988): contrasting modes of rifting: The Benue Trough and Cameroon volcanic lines, West Africa. Tectonics, 7(4), 775-784.

Okiwelu, A; Okwueze, C; Okereke, C and Osazuwa, I (2010): Crustal Structure and Tectonics of the Calabar Flank, West Africa, based on Residual Gravity Interpretation. European Journal of Scientific Research. 42(2): 195-203.

Olugbemiro, R. O; Ligouis, B and Abaa, S. I (1997): The Cretaceous Series in the
Chad basin, NE Nigeria: Source Rock Potential and Thermal Maturity. Journal of Petroleum Geology, 20, 51-58.

Petters, S. W (1982): Central West African Cretaceous - Tertiary benthic foraminifera and stratigraphy. Palaeontographica Abt. A179, 1-104.

Petters, S. W and Ekweozor, C. M (1982): Petroleum Geology of the Benue trough and southeastern Chad basin, Nigeria. AAPG Bulletin, 66, 1141-1149.

Rummel R, Rapp R. H, Sunkel H, Tscherning C. C (1988): Comparisons of global topographic-isostatic models to the Earth's observed gravity field. Reports of the Department of Geodetic Science and Surveying No. 388, Ohio State University, Columbus, Ohio.

Shemang, E. M; Ajayi, C.O and Jacoby, W. R (2001): A Magnetic Failed Rift Beneath the Gongola Arm of the Upper Benue Trough, Nigeria. Journal of Geodynamics, 32: 355-371.

Shemang, E. M; Jacoby, W. R and Ajayi, C. O. (2007): Global Journal of Geological Sci. 3(1): 61-69.

Ugbor, D. O and Okeke, F. N. (2010): Geophysical investigation in the lower Benue Trough of Nigeria using gravity method. International Journal of Physical Sciences, 5(11): 1757-1769.

Watts, A. B and Fairhead, J. D (1999): A process-oriented approach to modeling the gravity signature of continental margins. The Leading Edge. Pp. 258263.

Whiteman, A (1982): Nigeria: It's Petroleum Geology Resources and Potential. Graham \& Trorman, Londres, 394p.

Wright, J. B (1976): Fracture Systems in Nigeria and Initiation of Fracture Zones in South Atlantic. Tectonophysics, 34, 42-47. 